article differed. Some articles are more scientific than others, therefore, more questions are required to get a more indepth and easy-to-understand video abstract for the viewer.

Second, students went location scouting. The location for the interview needed to be in a professional setting that also was appropriate for the story. Location scouting was difficult for some students because they had to shoot in places off of Purdue's campus to accommodate their article's story.

Third, the students created their own shooting schedule that conformed with their clients' timeline.

The fourth stage of production included shooting the footage for both A roll and B roll. Some groups left campus in order to find their appropriate subjects. One group needed a mother and her baby to film for the "Infants' Speech Segmentation" article. Adam Krueger, a film and video studies major in his senior year, said, "Finding a mother and child willing to be in the video took a lot of searching." Another group needed to find sheep to film for "Determining the Role of DNTTIP1," so they sought out a local pasture.

The final and fifth stage was comprised of post-production, which is the editing stage that took place in a computer lab.

Adam Krueger described the class as a "very positive experience." Krueger went on to say, "I was really glad we were given this opportunity to work with a professional journal. This gave us real-world experience instead of just working in the classroom. I learned how to keep myself on track while going through the whole process, start to finish, of creating a professional, corporate-style video."

Students were not only taught the technical aspects of documentary filmmaking, such as composition of the interviewee shot and lighting techniques, but also the etiquette of conducting a professional interview. For example, when students experienced technical difficulties, such as the camera or audio recording device running out of battery life, they would inform the interviewee of the issue and speak with him or her as they resolved it.

Having an interesting and easy-to-understand story was one of the most important parts of the completed product. In one case, a group's rough cut was seven minutes long and included two stories, one about the article in general and one about a specific detail of the article. After viewing the rough cut, Chastain recommended that the group remove the detailed part even though it was interesting. This was done to make the piece shorter with a stronger single story that would not derail the main point of the article.

At the end of the semester, the final six videos were published on the JPUR website. Film and video are essential tools in the field of education. Through this course,

\section{LIST OF SELECTED ARTICLES}

"Out of the Box: Honors College in Action" by Eden

Holmes and Abigael Johnson

Video abstract produced by Hatim Al Taha

and Connor Geshay

"The Regulation of Mammary Cell Growth: Determining the Role of Clock" by Emily C. Erickson

Video abstract produced by LaQuan Lunford

"Infants' Speech Segmentation: The Impact of MotherInfant Facial Synchrony" by Allison Kish, Katie Courtaney, Adi Dilger, Tori Gallo, Lauren King, Amy Jarvis, Ambry

Roberson, Meredith Smith, and Serina Thottichira Video abstract produced by John Adam Krueger and Dominik Gliatis

"Determining the Role of DNTTIP1: Piecing Together the Callipyge Sheep Muscle Hypertrophy Pathway" by

Kimberly Lutz

Video abstract produced by Nathan Scott and Max Mullen

"We Can Take It!': Race and the Civilian Conservation Corps in Indiana, 1934-1941" by Katie Martin Video abstract produced by Nicholas Guerrisi and Michael Luken

"A New Strategy of Drug Delivery: Electric Field Distribution in Brain Tumor Due to Electroporation" by Junxing Shi Video abstract produced by Mallory Gieringer and Matthew Okerson

students learned the opportunities available to documentary producers, who can be utilized by academic entities to create visual abstracts. Because of the visual nature of film and video, the research can be understood clearly, easily, and can help translate it for a broader audience.

Al Taha, H. (2015). Out of the box: Roles of video in research. Journal of Purdue Undergraduate Research, 5, 108-109. http://dx.doi.org/10.5703/jpur.05.1.11

\section{Student Author}

Hatim Al Taha is a junior in the film and video studies program. He is striving to become a film director and writer. Before coming to Purdue, Al Taha was awarded the Outstanding Academic Achievement Award in Film/ Theater at Northern Virginia Community College.

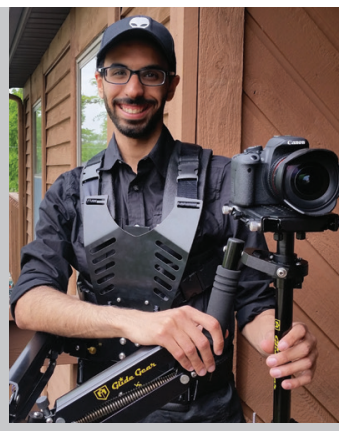

